\title{
On the Interplay of Ownership Patterns, Biodiversity, and Conservation in Past and Present Temperate Forest Landscapes of Europe and North America
}

\author{
Andreas Mölder ${ }^{1}$ (D) Malin Tiebel $^{2}$ (D) $\cdot$ Tobias Plieninger $^{2,3}$ (D)
}

Accepted: 6 August 2021 / Published online: 29 November 2021

(c) The Author(s) 2021

\begin{abstract}
Purpose of Review Ownership patterns and the associated management characteristics are related to forest structures, biodiversity patterns, and their conservation worldwide. A literature review on this topic is missing so far. We fill this gap with an emphasis on the temperate forests of Europe and North America. Mixed-ownership landscapes are the special focus of the analysis. In a first step, historical effects of ownership patterns on forest structure and biodiversity are elucidated. Second, connections between present-time forest ownership patterns and both forest structural and biodiversity patterns are analyzed. Finally, implications for integrative conservation management are evaluated with a special focus on mixed-ownership forest landscapes.

Recent Findings Close linkages between ownership type-specific forest management and particular forest structural and biodiversity patterns are identified for past and current forest landscapes. Both in Europe and North America, publicly and privately owned forests show comparable lines of historical development but with a time shift. Forest reserves and ancient woodland with long ecological continuity appear to be mainly connected with public ownership. A high diversity of management approaches and cultural landscape habitats is characteristic of non-industrial small private forests. In mixed-ownership landscapes, a more diverse mosaic of habitats has developed than in mono-ownership landscapes.

Summary We conclude that cross-boundary ecosystem management is crucial for effective conservation in present-day mixed-ownership landscapes. Integrative forest management that considers biodiversity and social-ecological aspects across ownerships is indispensable. We present a framework of implications for conservation management in mixed-ownership forest landscapes that build on each other and may enhance cross-boundary ecosystem management.
\end{abstract}

Keywords Mixed-ownership landscapes $\cdot$ Conservation planning $\cdot$ Forest management $\cdot$ Historical ecology $\cdot$ Ecological continuity $\cdot$ Social-ecological systems

\section{Introduction}

This article is part of the Topical Collection on Forest Management

Andreas Mölder

moelder@gmx.de; andreas.moelder@nw-fva.de

1 Department of Forest Nature Conservation, Northwest German Forest Research Institute (NW-FVA), Prof.-Oelkers-Straße 6, 34346 Hann. Münden, Germany

2 Department of Agricultural Economics and Rural Development, University of Göttingen, Platz der Göttinger Sieben 5, 37073 Göttingen, Germany

3 Faculty of Organic Agricultural Sciences, University of Kassel, Steinstraße 19, 37213 Witzenhausen, Germany
Nature conservation in forests strongly depends on motivated landowners who support and recognize the aims of conservation [1-3]. These conservation aims, however, vary among different forest ecosystems and so do the management targets of private or public forest landowners [4-6]. Forest owners are grouped into different ownership categories according to legal ownership status and property sizes $[7,8]$, often resulting in particular spatial forest ownership patterns at the landscape scale [9-11]. These ownership patterns and the related management characteristics are generally decisive not only for forest stand structures [9, $12-14,15 \bullet \bullet, 16]$ but also for forest biodiversity patterns and nature conservation planning worldwide [12, 17-20]. This 
is particularly true for mixed-ownership landscapes, where certain ownership mosaics or patterns have been identified as significant determinants of forest habitat conditions and species assemblages [9, 21].

However, a literature review focusing on the interplay of forest ownership patterns, biodiversity, and conservation management in mixed-ownership landscapes is missing so far. Given the major impacts of landownership policies on biodiversity patterns, these relationships require much more scientific and practical consideration [19]. This study aims to fill this gap with an emphasis on the temperate zones in Europe and North America. Here, mixed-ownership forest landscapes are very common, whereby the forestland belonging to different forest ownership types is spatially interwoven in different intensities [9, 22-24].

We are aware that this literature review is a great challenge and that some aspects may remain unconsidered or relationships may deviate at regional scales. But we are convinced that our overview sparks scientific interest in the often underestimated but important ownership-biodiversity interactions and that we present a suitable framework for effective conservation management in mixed-ownership forest landscapes.

We distinguish three main categories of forest ownership: publicly, privately, and commonly owned forests. Within the category of publicly owned forests, where public owners are institutional bodies that claim to represent the general population [7], state-owned forests (res publicae) are the most important subtype in most countries. Another common subtype of publicly owned forests is municipal or communal forest owned by towns, cities, or villages (res communalis). When referring to private forest ownership (res privatae), the legal status of the proprietor and the size of the forest holding are commonly used to differentiate between the subtypes. Large private forests, either owned by individuals, industrial companies, or institutions like churches, can reach sizes between a few hundred and several thousand hectares. Small private forests, at the other end of the size range, are frequently much smaller than 10 hectares [25••]. Also termed non-industrial, smallholder, or family forests [26•], small private forests are abundant both in central and

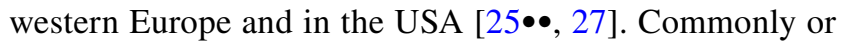
community-owned forests (res communis) are managed by a group of co-owners that have a governance structure responsible for assigning usage and other rights [25••]. Much more abundant in some European countries than in North America [25••], this ownership type is characterized by a great diversity of specific community forest arrangements [28•].

While recent studies have highlighted the need for research in historical ecology to inform the implementation of forest conservation today $[29,30,31 \bullet \bullet, 32]$, the role of forest ownership patterns in this context has been widely neglected [33]. This is surprising because the legacy effects of ownership-related historical forest development processes can be expected to be crucial for biodiversity patterns and conservation efforts in present-day forests. Due to the longevity of forest ecosystems, specialized woodland plants and animal species depending on long-term ecological continuity $[32,34]$ are most likely to be affected by legacy effects. Of particular importance are habitat-shaping forest management techniques such as coppicing that have been linked with both certain ownership categories and the occurrence of specialized woodland species. Coppicing means repeatedly felling trees at the base (or stool), and allowing them to regrow, in order to provide a sustainable supply of wood [35-37].

For these reasons, we first take a historical look at the effects of past forest ownership patterns on former forest structure and biodiversity, whose legacies are still decisive for present-day forest ecosystems. Thus, this analysis sets the scene for the subsequent section, where the main connections between present-time forest ownership patterns and both forest structural and biodiversity patterns are elucidated. Recent forestry and conservation management approaches are considered in this context as well. The insights derived from these two sections complement each other and meet the need for a holistic view in terms of longterm forest-landscape development. Based on the previous findings and taking into account further ownership-related literature on forest conservation and management, we finally present and synthesize the main implications for conservation management in mixed-ownership forest landscapes. By implications, we mean a series of measures and strategies that build on one another and are intended to improve integrative and effective conservation management. Given this background, our literature review addresses three research questions:

1. How did the historical development of forest ownership patterns shape forest structural and biodiversity patterns? 2. What are the main connections between forest ownership patterns and both forest structural and biodiversity patterns in present-time forest landscapes?

3. What are the main implications for conservation management in mixed-ownership forest landscapes?

\section{Materials and Methods}

\section{Study Area}

This review is focused on the cool and cold temperate zones in Europe and North America [38], which include the majority of European countries, most of the USA, and southern Canada. The shares of publicly, privately, and commonly owned forests vary considerably among the different 
continents and countries. In overview statistics, commonly owned forests are mostly assigned to one of the two other ownership categories (e.g., [25••]). Following this perception, overall ownership in Europe's forest area (excluding the Russian Federation, which is mainly located in Asia) was quite equally split between public (44\%) and private (56\%) ownership in 2015. With regard to the forest area of North America (here: Canada and the USA), public ownership (68\%) exceeded private ownership (32\%). Particularly in Europe, however, there is a wide range behind these averages, from $100 \%$ public ownership in Georgia or Ukraine, through more evenly split ownership in Germany (52\% public/48\% private), Ireland (53\%/47\%), or Lithuania (60\%/40\%), to countries with prevailing private ownership such as Austria (18\%/82\%), Sweden (26\%/74\%), or France $(24 \% / 76 \%)$. Overall, small-scale land holdings predominate in European private forests, where 88\% of all forest holdings are smaller than 10 ha. Concerning North America, 37\% of the forests in the USA are public and $63 \%$ private, while in Canada publicly owned forests predominate with a share of 91\%. As in Europe, most of the private forestland in the USA is owned by individuals and families (64\%) with an average property size of $14.8 \mathrm{ha}$. The share of business entities in the private forest area is highest in the USA and Sweden (30\%), followed by Belgium (25\%) and France (23\%). Private common ownership is particularly abundant in Slovakia (61\%) and Switzerland (43\%), and tribal or indigenous private forest ownership occurs only in Norway (12\%) and the USA $(2 \%)[25 \bullet \bullet]$.

Concerning areas of particular conservation concern, the terrestrial protected area coverage of whole Europe amounts to 13\% [39]. Within the European Union (EU), the Natura 2000 system, which is the largest coordinated network of protected areas worldwide, covers $18 \%$ of EU countries' land surface [40]. Half of the area protected within the Natura 2000 system is forested [41]. Both in the USA and Canada, the terrestrial protected area coverage amounts to $12 \%$ [42, 43].

\section{Literature Searches}

Literature searches were conducted using the citation and abstract database Scopus. The query was last repeated on April 30, 2021. The applied search terms are given in Online Resource A. No restrictions were made regarding the time since publication. We used not only the search term "forest" ("forest*" in search term 1), but also the terms "woodland," "wood," or "woods" ("wood*" in search term 1), since these terms are used synonymously in many European studies. We are aware, however, that "woodland" and "woods" refer to low-density and open forest habitats in North America. This terminology was considered when evaluating the literature. Search term 2 ("owner*" or "tenure") ensured that only studies were included that deal with forest ownership issues. Apart from the term "histor*," which was aimed at identifying historical relationships, the third term of each literature database search included important aspects of forest biodiversity conservation. Besides species groups of conservation concern (e.g., "beetle*" or "bird*"), also structural forest attributes that provide important habitat for a variety of taxa (e.g., "microhabitat*" or "deadwood") were considered here.

The titles of the resulting articles were reviewed to evaluate if they generally fit the aims and area of interest of this study (step 1). Further evaluation was carried out by reading the abstracts of the retained articles (step 2). We then only considered studies that focused on the temperate zones in Europe and North America. All articles with positively evaluated abstracts were read, and additional works cited in the reference lists of those articles were analyzed subsequently (step 3). Concerning the history of forest ownership patterns (research question 1), monographs on forest history were considered as well. A Zotero digital bibliographic library was compiled to organize the selected references by topics and research question.

As for research question 2, a systematic approach was used to determine the main connections between forest ownership patterns and both forest structural and biodiversity patterns in present-time forest landscapes. Eligible studies had to be conducted in mixed-ownership landscapes and to analyze the effects of both the spatial arrangement and the management characteristics of different ownership categories (i.e., the forest ownership patterns) on biodiversity and conservation values. In this way, we obtained 22 core studies (Table 1, Online Resource B). Twelve of these core studies took place in Europe, and ten had been conducted in North America.

To derive the main implications for conservation management in mixed-ownership forest landscapes (research question 3), the selected studies were evaluated in view of conservation-related recommendations and strategies. We arranged these recommendations into groups and sub-groups of related measures and strategies (i.e., implications) and compiled a stepwise framework of implications that build on one another.

\section{Historical Effects of Ownership Patterns on Forest Structural and Biodiversity Patterns}

\section{Europe}

\section{Medieval and Early Modern Periods}

Already in ancient times, there were a variety of public and private forest ownership types in those parts of Europe that 
Table 1 Overview of the 22 core studies comparing forest structural and biodiversity patterns among different ownership types in mixed-ownership landscapes (see Online Resource B for more details)

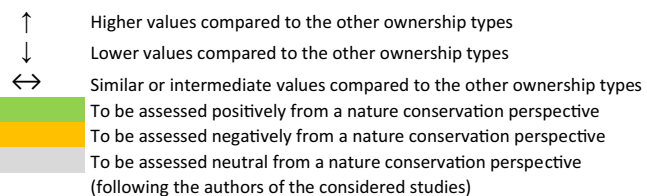

\begin{tabular}{|c|c|c|c|c|c|c|c|c|c|c|}
\hline \multirow[b]{3}{*}{ Reference } & \multirow[b]{3}{*}{ Country } & \multirow[b]{3}{*}{ Region } & \multirow[b]{3}{*}{\begin{tabular}{|l} 
Research object \\
(biodiversity, forest structure)
\end{tabular}} & \multicolumn{7}{|c|}{ Ownership types } \\
\hline & & & & \multicolumn{3}{|c|}{ Publicly owned } & \multicolumn{3}{|c|}{ Privately owned } & \multirow[t]{2}{*}{$\begin{array}{c}\text { Commonly } \\
\text { owned }\end{array}$} \\
\hline & & & & $\begin{array}{c}\text { No } \\
\text { specification }\end{array}$ & $\begin{array}{l}\text { State/ } \\
\text { Country }\end{array}$ & Municipal & \begin{tabular}{c|} 
No \\
specification
\end{tabular} & $\begin{array}{l}\text { Large } \\
\text { private }\end{array}$ & $\begin{array}{c}\text { Small } \\
\text { private }\end{array}$ & \\
\hline Lovett-Doust et al. (2001) [22] & Canada & Southern Ontario & $\begin{array}{l}\text { Biodiversity values (vegetation types, rare } \\
\text { plants and birds) }\end{array}$ & $\uparrow$ & & & $\downarrow$ & & & \\
\hline Maltamo et al. (1997) [77] & Finland & Central Finland & Tree stories, diameter range & & $\downarrow$ & & & $\downarrow$ & $\uparrow$ & \\
\hline Larrieu et al. (2017) [36] & France & Southwestern France & Tree-related microhabitats & $\uparrow$ & & & $\leftrightarrow$ & & & \\
\hline Bergès et al. (2013) [19] & France & Northern France & Forest plant species & & $\uparrow$ & $\uparrow$ & & & $\downarrow$ & \\
\hline \multirow[t]{3}{*}{ Reise et al. (2019) [24] } & \multirow[t]{3}{*}{ Germany } & \multirow[t]{3}{*}{ Whole country } & Forest bird communities & & $\uparrow$ & $\uparrow$ & $\downarrow$ & & & \\
\hline & & & Deadwood volume & & $\uparrow$ & $\uparrow$ & $\downarrow$ & & & \\
\hline & & & Percentage of mature forests & & $\uparrow$ & $\uparrow$ & $\downarrow$ & & & \\
\hline Johann \& Schaich (2016) [147] & Germany & Southwestern Germany & Tree-related microhabitats & & $\downarrow$ & $\downarrow$ & & & $\uparrow$ & \\
\hline Schaich \& Plieninger (2013) [139] & Germany & Southwestern Germany & $\begin{array}{l}\text { Structural diversity, dead wood, carbon } \\
\text { storage capacity }\end{array}$ & & $\downarrow$ & $\downarrow$ & & & $\uparrow$ & \\
\hline Rendenieks et al. (2015) [130] & Latvia & Northern Latvia & $\begin{array}{l}\text { Vertical canopy structure, tree species } \\
\text { richness }\end{array}$ & & $\downarrow$ & $\downarrow$ & & & $\uparrow$ & \\
\hline Bujoczek et al. (2021) [129] & Poland & Whole country & Deadwood volume & & $\uparrow$ & & $\downarrow$ & & & \\
\hline Kuemmerle et al. (2009) [92] & Poland & Southeastern Poland & Anthropogenic disturbance & & $\downarrow$ & & $\uparrow$ & & & \\
\hline \multirow[t]{2}{*}{ Żmihorski et al. (2010) [126] } & \multirow[t]{2}{*}{ Poland } & \multirow[t]{2}{*}{ Central Poland } & Tree diameter and basal area & & $\uparrow$ & & & & $\downarrow$ & \\
\hline & & & Share of non-native species & & $\uparrow$ & & & & $\downarrow$ & \\
\hline Torras et al. (2012) [128] & Spain & Northeastern Spain & Biodiversity indicators & $\leftrightarrow$ & & & & & $\uparrow$ & \\
\hline Holmgren et al. (2010) [148] & Sweden & Central and northern Sweden & Biodiversity indicators & & $\leftrightarrow$ & & & $\leftrightarrow$ & $\leftrightarrow$ & $\leftrightarrow$ \\
\hline Hobart et al. (2019) [21] & USA & Sierra Nevada, California & Benefits to spotted owls & $\leftrightarrow$ & & & $\uparrow$ & & & \\
\hline Maslo et al. (2015) [117] & USA & New Jersey & Forest bird species & & $\uparrow$ & $\uparrow$ & $\downarrow$ & & & \\
\hline \multirow[t]{2}{*}{ Zheng et al. (2010) [125] } & \multirow[t]{2}{*}{ USA } & \multirow[t]{2}{*}{ New England states } & Forest aboveground biomass & $\uparrow$ & & & $\downarrow$ & & & \\
\hline & & & Landscape fragmentation & $\downarrow$ & & & $\uparrow$ & & & \\
\hline Riitters et al. (2012) [113] & USA & Eastern United States & Fragmentation of forest communities & $\downarrow$ & & & $\uparrow$ & & & \\
\hline Kennedy et al. (2008) [127] & USA & Coastal Oregon & Dead wood & & $\uparrow$ & & $\downarrow$ & & & \\
\hline \multirow[t]{4}{*}{ Ohmann et al. (2007) [133] } & \multirow[t]{4}{*}{ USA } & \multirow[t]{4}{*}{ Coastal Oregon } & Late successional and old-growth forest & & $\uparrow$ & & & $\downarrow$ & $\downarrow$ & \\
\hline & & & Diversity of forest ages and structures & & $\uparrow$ & & & $\leftrightarrow$ & $\downarrow$ & \\
\hline & & & $\begin{array}{l}\text { Early-successional forest, mixed hardwood- } \\
\text { conifer forest, legacy down wood }\end{array}$ & & $\leftrightarrow$ & & & $\uparrow$ & $\leftrightarrow$ & \\
\hline & & & $\begin{array}{l}\text { Diverse young forest, abundance of } \\
\text { hardwood trees }\end{array}$ & & $\downarrow$ & & & $\downarrow$ & $\uparrow$ & \\
\hline McComb et al. (2007) [179] & USA & Coastal Oregon & Predicted future bird habitats & & $\uparrow$ & & & $\leftrightarrow$ & $\leftrightarrow$ & \\
\hline \multirow[t]{2}{*}{ Stanfield et al. (2002) [9] } & \multirow[t]{2}{*}{ USA } & \multirow[t]{2}{*}{ Coastal Oregon } & Mature forest cover & & $\uparrow$ & & & $\downarrow$ & $\downarrow$ & \\
\hline & & & Diversity of cover classes & & $\downarrow$ & & & $\downarrow$ & $\uparrow$ & \\
\hline Easterday et al. (2018) [15] & USA & California & Declines in large trees & $\leftrightarrow$ & & & $\leftrightarrow$ & & & \\
\hline
\end{tabular}

belonged to the Roman Empire. For the regions outside the Empire, it can be assumed that forests were regarded as common resources that were free to use [44]. Following the Migration Period, a century-long process of forest ownership development began in most of Europe. From the seventh century onwards, sovereigns reserved large parts of "ownerless" woodland for their own usage, mostly as hunting reserves-which is the original meaning of forest (Latin forestis, forestum). Also, freemen, monasteries, and settlement communities were able to obtain forestland for their purposes either as private tenure or as common property. The same applied to forest usage rights $[45,46]$. 
Fig. 1 Chronology of important developments in western and central European forest ownership history

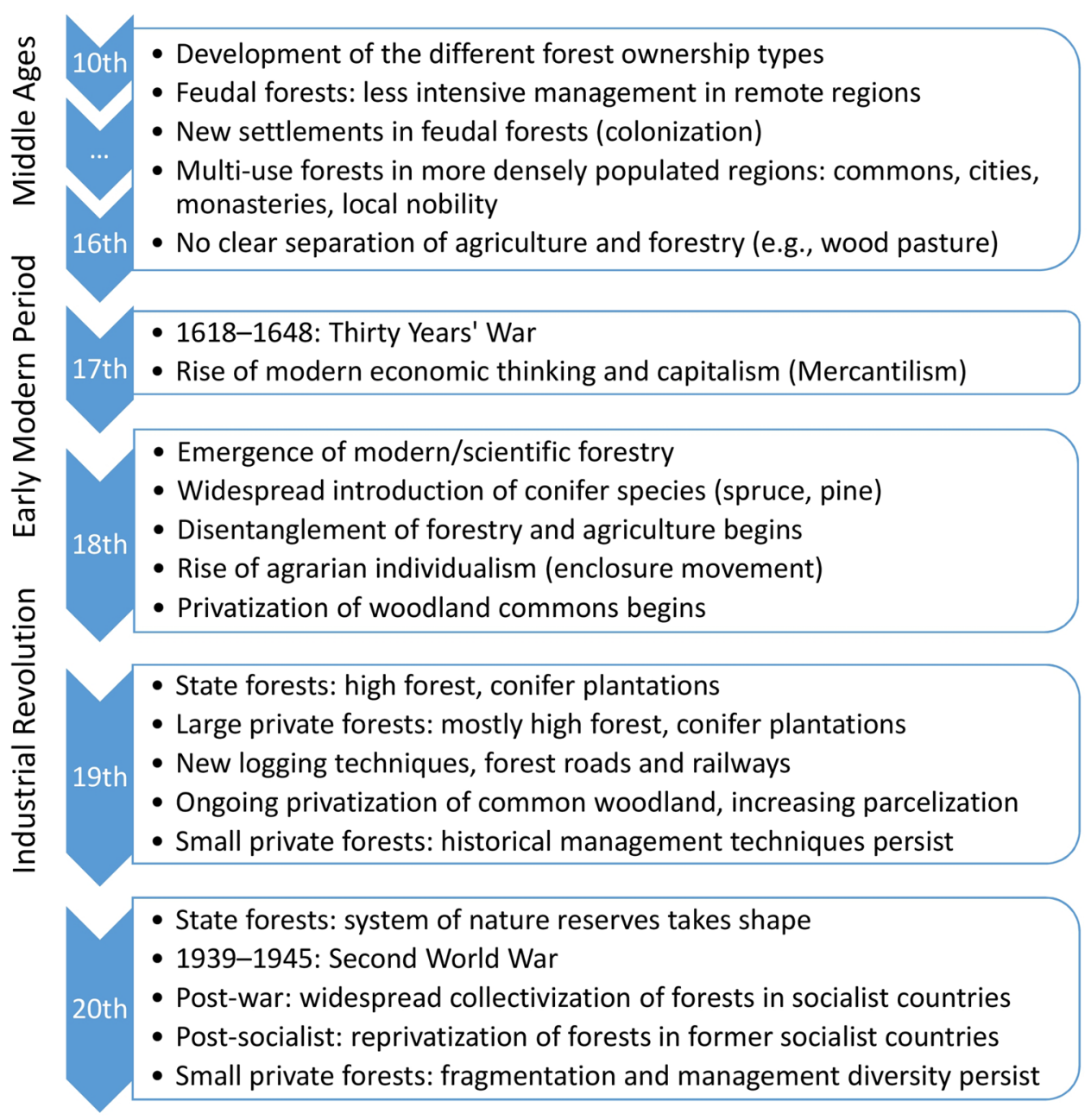

As a result of this development, large forests remained reserved for the privileged use of sovereigns or states in the medieval and early modern periods (Fig. 1). While some of these state-owned or feudal forests were managed in a relatively coordinated manner for centuries [47], others in remote and sparsely populated regions remained nearly untouched [48, 49]. Woodland in more densely populated regions frequently became the intensively used common property of the local population $[50-55,56 \bullet]$, the municipal property of cities, or private property of the church and the local nobility [35, 50, 57]. In some cases, however, members of one ownership class had chartered usage rights or usufruct in the woodland of other ownership classes. This was the case, for example, for fuelwood collection, wood-pasture (of livestock), or pannage, which is the practice of releasing domestic pigs into a forest to feast on fallen acorns, beechmast, and chestnuts [50-52, 57, 58]. The consequences of these different ownership types for forest structure and biodiversity were crucial and dependent on the landscape context: While state or feudal ownership in remote or inaccessible forest areas frequently preserved semi-natural forest communities and high volumes of live or dead wood biomass [49, 59], the situation was different in more densely populated areas, where multiuse forests became part of intensively managed cultural landscapes [35, 60, 61]. Here, management techniques like coppicing, coppicing with standards, and wood pasturing created suitable habitats for warmth- and lightdemanding plant and insect species. In particular, oak woodland (Quercus robur, Q. petraea) and its associated biodiversity benefited from these kinds of management that frequently sustained century-long ecological continuity [34, 35, 57]. However, also the extent of deforestation, e.g., for settlement and agricultural purposes in the medieval period, was frequently determined by the type of land ownership. In the German lands, for example, sovereigns promoted the systematic colonization of stateowned woodlands in their ancestral or newly conquered territories [49, 62, 63]. 


\section{Rise of Scientific Forestry in the Eighteenth and Nineteenth} Centuries

When scientific forestry emerged in the eighteenth century (Fig. 1), forest ownership and the related woodland structural and biodiversity patterns were subject to large changes. This development was closely connected to the rise of modern land-use schemes and the emergence of modern thinking on forest resource economy [51, 64, 65]. In particular, governments introduced efficient management for wood production in state-owned forests and strived for quitting the usage rights of external persons or institutions [66]. High forest management became the new silvicultural standard, conifers were introduced in large areas, and century-old multi-use forest management techniques were increasingly abandoned $[65,67,68]$. Furthermore, changing economic conditions, new logging techniques, and the construction of roads and forest railways for timber transport accelerated the intensified utilization of formerly inaccessible and thus unmanaged woodland [48, 49, 65]. Since even short periods of depletion or spontaneous land-use changes might cut the temporal and spatial thread of ecological continuity, forest habitat conditions and thereby plant and animal assemblages were thus crucially changed. Most notably, the intensification and specialization trends of modern post-eighteenth century forestry and agriculture led to the extensive loss of both transitional woodland habitats and their specialized species assemblages [56•, 69, 70]. But also old-growth structures, large old trees, and the amount of deadwood were considerably diminished, with negative consequences for saproxylic and tree cavity-dwelling species [49, 71]. On the other hand, nature sanctuaries or even systems of nature reserves have been established from the late nineteenth century onwards preferably in the publicly owned forest $[49,66,72]$.

\section{Abolition of Commons and Privatization of Common Woodland}

Furthermore, European state authorities promoted or even forced the abolition of commons and the privatization of common woodland from the eighteenth century onwards (Fig. 1). Beginning with the enclosure movement in Great Britain [58], woodland held in common for centuries was changed to private land and thereby divided among the commoners and other institutions or persons who held usage rights in the commons. Prominent examples of this procedure are to be found in France [73], Denmark [51], and the German lands [74]. This development was a consequence of an intellectual current that later became known as "agrarian individualism". Private property was henceforth regarded as an essential prerequisite for efficient management and thus increased yields in agriculture and forestry $[50,51$, $56 \bullet, 58,73,74]$. In many regions, the result was an extreme parcelization of forest ownerships in the late eighteenth and early nineteenth century with property sizes of only a few hectares. Additionally, the recurrent division of estates among the heirs [75] and the abolishment of feudalism with subsequent division of former feudal estates [76] increased forest ownership parcelization. In contrast to arable land, land consolidation was not systematically conducted in these private woodlands, so that the parcelization of small private forests frequently persisted until present times. In many regions, woodland privatization and parcelization resulted in an elevated diversity of management approaches, management intensities, and tree species, and thereby forest habitats, but also in deforestation and landscape fragmentation [56•, 76-79]. Historical management techniques like coppicing, coppicing with standards, and wood pasturing lasted longer in small private forests than in state-owned forests $[55,80]$. In some regions, however, the institutional structures of commonly owned forests persisted until present times [28 $\bullet$, $53,54,61]$. The same is true for the application of historical management techniques also in these forests, particularly coppicing [61] or pollarding. This pruning system involves the periodic removal of the upper branches of a tree and is aimed at producing fuelwood and fodder to feed livestock [81].

\section{Municipal and Larger Private Forests}

With regard to municipal forests and larger private forest estates that were often owned by the nobility, the development of modern forestry from the late eighteenth century onwards varied among regions and according to individual management targets. In general, municipal forests often showed a long ownership and management continuity that was aimed at the enduring welfare of the community [82, 83]. For these reasons, long ecological and structural continuity can be assumed for most municipal forests. Large private woodland estates tended to be managed intensively for high profits, including forest clearing for agricultural land, but there were also cases of cautious management or even the establishment of nature reserves in the nineteenth century [84-86]. Therefore, although negative influences on ecological continuity and woodland habitat specialist species can generally be assumed for large private woodland estates, regional conditions and societal developments must always be taken into account.

\section{Countries with Socialist Governments}

In the mid-twentieth century (Fig. 1), forest ownership patterns and thereby ownership continuity underwent large changes caused by collectivization in those European countries with socialist governments [75, 87-89]. Furthermore, expropriation after the Second World War resulted 
in widespread nationalization of forests and natural oldfield succession on abandoned former private farmland [63, 90, 91]. In particular, centralized and intensified forestry in socialist countries caused homogenization of both stand structures and tree species composition, the latter with an emphasis on conifers [87-89]. Furthermore, collectivization and increased forest management intensity resulted in severe interruptions of ecological continuity, for example, in Romanian old-growth beech forests [89]. Small private forest ownership, however, remained intact in some countries even during socialist times [75, 92]. Reprivatization and institutional instability in the post-socialist transition time finally led to increased anthropogenic disturbance rates $[89,92]$. These were, for example, in southeastern Polish private forests about five times higher than on adjacent public lands and negatively affected ecological continuity [92]. Currently, the development of forest ownership patterns in former socialist countries and the related structural and socio-ecological changes are the focus of several research activities [88, 93••].

\section{North America}

\section{Forest Use by Native Americans}

The vast forests of North America were shaped by Native Americans for millennia [94, 95]. Land was considered a common resource and private property rights in forests and other landscape components did not exist before European settlement, since population densities were too low to warrant the development of such rights. When conflicts occurred between neighboring tribes over the use of natural resources, these conflicts were not sufficient to overcome the transaction costs associated with private ownership of land [96]. The main tool of the Native Americans for modifying the forests was fire. They had become experts in using fire for various purposes to enhance their food supply and improve the quality of their lives [97]. For example, fire was used to encourage fruit and berry production, to create and maintain open woodlands, or to expose acorns and chestnuts for collection. By skillfully using fire as a powerful tool, Native Americans made extensive modifications to the vegetation over most of North America [94, 97, 98].

\section{Forest Exploitation in the Nineteenth Century}

Following the European settlement from the seventeenth century onwards, the forests of North America were exposed to dramatic changes. Early settlers and homesteaders considered the forests an obstacle to be overcome [99]. Especially in the nineteenth century, intensive forest exploitation and deforestation moved increasingly westward. Despite the gradual development of public and private forest ownership structures that were comparable to European conditions, there was no national policy on forestry and no practice of planned forestry until the 1880s [94, 99, 100]. Already in 1819, the French botanist François André Michaux (1770-1855) compared the forest ownership structures between Europe and North America and critically pointed out [101]:

It may not be improper to observe that the Europeans have great advantages over the Americans in the management of woods. The principal forests are in the hands of the governments, which watch over their preservation with a solicitude dictated by imperious necessity. Experience has amply demonstrated that no dependence can be placed, for the public service or the general supply, upon forests that are private property: falling sooner or later into the hands of persons eager to enjoy their price, they disappear and give place to tillage. In America, on the contrary, neither the federal government nor the several states have reserved forests. An alarming destruction of the trees proper for building has been the consequence - an evil which is increasing and which will continue to increase with the increase of population.

\section{The Concepts of Forest Conservation and Preservation}

With the ongoing spread of forest destruction, first voices were raised in favor of forest conservation and sustainable forest management [99]. Among these voices, George Perkins Marsh (1801-1882) was of particular concern, since he skillfully highlighted the importance of different ownership types for forest conservation in the USA. In his seminal book Man and Nature, Marsh reflected not only experiences from Europe but also the USA and highlighted, like already Michaux [101], the great importance and benefits of public forest ownership [82]: "Fortunately, some of the American states, as well as the governments of many European colonies, still retain the ownership of great tracts of primitive woodland." Therefore Marsh deemed it a "great misfortune to the American Union that the State Governments have so generally disposed of their original domain to private citizens." He supported proposals that the state should declare the remaining forest the inalienable property of the commonwealth and considered it "desirable that some large and easily accessible region of American soil should remain, as far as possible, in its primitive condition, at once a museum for the instruction of the student, a garden for the recreation of the lover of nature, and an asylum where indigenous tree, and humble plant that loves the shade, and fish and fowl and four-footed beast, may dwell and perpetuate their kind, in the enjoyment of such imperfect protection as the laws of a people jealous of restraint can afford them." Concerning 
possible financial losses that the public treasury incurs from not selling forestland, Marsh emphasized that "the forest alone, economically managed, would, without injury, and even with benefit to its permanence and growth, soon yield a regular income larger than the present value of the fee."

Such considerations provided the impetus for the competing preservationist and utilitarian philosophies in the late nineteenth century USA, when the protection of the environment from human impacts (preservation; John Muir's approach) was faced with the sustainable use of natural resources for human benefits (conservation; Gifford Pinchot's approach). In the historical view, these opinions of preservation and conservation resulted in divergent and sometimes conflicting policies affecting public lands: While national parks (preservation) were designated on the one hand, federal forest reserves and national forests were committed to multiple-purpose management (conservation) on the other both in the USA [102, 103] and in Canada [104]. In contrast to Europe, modern forestry, silviculture, and forestry education in the USA did not begin on federal or national lands but in the state lands and particularly on private lands. The federal government, however, recognized the need for sustainable forest management and well-trained forestry staff, given the overcutting of timber on many private lands $[99,105]$.

\section{Forest Management and Conservation After the Second World War}

The economic boom following the Second World War put particular pressure on publicly owned forests and their biodiversity: Before the war, national forests were used as a timber reserve and wood was mainly harvested from private lands. After the widespread depletion of those private timber resources, harvesting rates on publicly owned forestlands

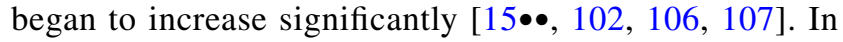
California, for example, the legacies of this management intensification are still visible in today's forest structure and vary among ownership classes. Among other differences, private timberland, national forests, and present-day national parks and wilderness areas showed consistent and more pronounced structural changes (loss of large trees and basal area, increase in small trees and total trees) in the twentieth century than private protected forestland or forests in state and regional parks $[15 \bullet \bullet]$. Concerning the Oregon Coast Range, Kennedy and Spies [106] concluded that large and very large conifers today primarily occur in publicly owned forests that are managed by the US Forest Service, since these forests exhibit a shorter history of intensive use than privately owned forestland, where logging already began in the late nineteenth century.

After the United Nations Conference on the Human Environment (held in 1972), forest conservation and integrative forest management became increasingly important issues worldwide [107, 108]. In the publicly owned forests of the Pacific Northwest, variable retention harvesting was developed as an important forest management technique to maintain wildlife habitat and other important forest functions [107]. The 1992 Convention on Biological Diversity was another key stimulus for increased conservation. Retention forestry became a successful element of integrative forest management and widespread worldwide since then, with specific adaptations for different forest ecosystems [109].

\section{Specific Developments in Eastern North America}

As in Europe, specific historical effects of forest ownership patterns on forest structure and biodiversity were found on the regional scale. This is particularly true for eastern North America with its long history of European settlement and its historically greater settlement density. Most forests in the northeastern USA are under private individual ownership since European settlement, and this ownership pattern has affected forest change more than natural disturbances [110]. The consequences for ecological continuity were crucial as the percentage of known primary forests is proportionately higher on public lands than on private lands both in the eastern USA and in eastern Canada $[111,112]$. Forests that remained intact mainly in remote or steep locations had become publicly owned because of their inaccessibility [113]. This is another good example of the interaction between the physical environment and land ownership patterns [114]. Regarding ecological continuity in private lands, Davis [111] pointed out that "huge industrial forests, fragmented private ownerships, and a myriad of owner preferences practically exclude the possibility of long-term, large-area dedication to old-growth on private lands." Private forest estates in this region were, moreover, frequently subject to high ownership turnover and thereby lacked forest management or even woodland cover continuity from the eighteenth century onwards $[82,100]$. On the contrary, there are rare cases when long-term family ownership successfully sustained tracts of old-growth forest for generations even on private land [111]. Most notably, many private forests feature woodland continuity only since the late nineteenth or even the early twentieth century, since they originated from natural old-field succession on abandoned farmland [27, 100, 110, 112, 115]. These historical processes in connection with forest fragmentation and ongoing parcelization of private forestland are major drivers of tree species composition, forest structure, successional stage, and thereby the composition of plant and animal assemblages in eastern North American forests $[110,113,115-118]$. 
Parcelization of Private Forest Lands in the Twentieth Century

In a remarkable congruence to Europe, but with a time shift of about 100-150 years, forest fragmentation and the parcelization of private forestland into smaller ownerships became major issues throughout the USA from the early twentieth century onwards [27, 110, 116, 119-121]. Important driving forces behind this development were property divisions among the heirs of deceased forest owners, insecurity about property rights, rural and suburban sprawl, and nature-oriented lifestyles with people who strive for their own woodland lot $[120,122]$. The ecological consequences of this development appeared to be manifold and range from the loss of wildlife habitat to settlements and roads $[110,116,120]$ over the viability reduction of local animal populations $[115,116,120]$ to a decrease in early successional vertebrate habitats [115]. The parcelization of large private forest ownerships into numerous smaller ones may also impede the efficient use of silviculture to manage the forest for wildlife resources [110, 123]. Long-term public forest ownership, on the other hand, appeared to constrain forest fragmentation [113, 117], regardless of the percentage of wilderness [124].

\section{Land Tenure and Biodiversity Patterns in Present-Time Forest Landscapes}

\section{Differences Between Publicly and Privately Owned Forests}

Our literature selection yielded 22 core studies that linked land tenure with patterns of biodiversity and forest structure (see Table 1 and Online Resource B for an overview). Publicly owned forests generally appeared to be characterized by more pronounced old-growth or ancient woodland structures, a higher abundance of typical forest species, and less landscape fragmentation than privately owned forests (when holding sizes are not considered). In particular, this is true for forest bird species in Central Europe [24] and eastern North America [22, 117], the amount of growing stock in eastern North America [125] and central Europe [126], the degree of landscape fragmentation in northern Europe [77] and eastern North America [113], and the amounts of deadwood or large-diameter trees in western North America [127] and Western and Central Europe [24, 128, 129].

The differences between publicly and privately owned forests cannot be explained solely by recent forestry and conservation management decisions, but also by the legacy effects of past management and the characteristics of the physical environment. However, current management is indirectly affected by the historical development of forests. As stated above, continuous tracts of natural or semi-natural forests are mostly associated with long-term public ownership. Furthermore, these areas often stand out as old-growth or ancient woodland and are therefore characterized by long-term ecological continuity that makes them suitable for protected area designations. Consequently, large nature reserves, national parks, and other conservation areas are mostly associated with long-term public ownership both in Europe and in Northern America [24, 49, 125, 129-131]. Furthermore, the establishment of protected areas tends to be easier in publicly owned forests than in private land if the policy supports such efforts. The same is true for modern concepts of integrative multifunctional forest management and retention forestry, which are particularly implemented under public ownership [4, 19, 22, 36, 125, 128, 130]. For these reasons, the occurrence of species that are linked to old-growth structures and long-term ecological continuity is frequently associated with ancient, natural or semi-natural, publicly owned woodland under conservation-oriented forest management [19, 24, 132]. It has to be kept in mind, however, that regional distinctions and historical developments can lead to deviations from these general relationships [15••, 86], most particularly in those European countries with former socialist governments.

\section{Characteristics of Large Private Forests}

When considering private property sizes, most of the conservation values appear to be linked to smaller rather than larger property sizes (Table 1, Online Resource B). This is related to forest management intensity that appeared to be generally higher in larger private forests (ranging from a few hundred to several thousand hectares). Such forests may be owned by industrial companies, and the respective forest management plans particularly target high economic viability. Clear-felling, a tendency towards conifer plantations, and short rotation cycles are more abundant in such large privately owned forests than in most public forests both in North America [9, 24, 125, 133] and in Europe [24]. Concerning the post-wildfire forest regeneration of mixedconifer forests in the Sierra Nevada (California), the silvicultural treatments in private industrial forests were more intensive and uniform than those on public forestland [134]. Conservation-oriented silviculture and the retention of oldgrowth structures are less common in large private forests or depend on financial compensation or guidelines set by conservation plans and certification schemes [36, 135]. In this regard, Larrieu et al. [36] found that both the density and diversity of tree-related microhabitats after harvesting operations tended to be lower in private stands without any (conservation) management plan than in public and private forests with formal management plans. 
However, large private forests are not generally lacking conservation values. Even if particular species that depend on old-growth structures and long ecological continuity may be absent, appropriate habitats for early-successional forest species of conservation concern or large amounts of legacy woody debris may occur $[115,133]$. It has to be kept in mind, though, that young forest plantations do not provide the ecological diversity that develops after stand-replacing or partial natural disturbances such as fire and wind [136]. In this regard, open forest management for early successional birds has been identified as an important conservation objective in the eastern USA [137].

\section{Characteristics of Small Private Forests}

In contrast to large private forests, small private forests are frequently characterized by lower or highly varying management intensities as compared to other forest ownership types that follow formal forest management plans $[27,77,133$, $138,139]$. Besides possible negative effects of forest fragmentation on the landscape level (as highlighted in the "historical effects" section above [77, 80, 110]), several positive implications of this particular management are characterizing the importance of small private forests for biodiversity conservation both in Europe and western North America. Owing to diverse management targets or even non-targets $[140,141]$, which range from natural forest development over occasional firewood cutting or coppicing to regular high forest management, a very diverse mosaic of habitats has developed in these woodlands [77, 80, 130, 133, 142, 143]. In accordance with the environmental heterogeneity hypothesis [144], a positive relationship between the pronounced management and structural diversity in small private forests and forest biodiversity patterns has been observed [80, 143, 145]. Most notably, historical management practices such as coppicing, wood pasture (of livestock), or litter-racking (fallen leaves or needles were used as stable litter), which have been abandoned in European public or large private forests many decades ago, have persisted in small private forests much longer. The same is true for structural remnants of these management practices, e.g., stored coppices, deadwood-rich coppice stools, or "candelabra-like" trees that were once pollarded (Fig. 2). Therefore, small private forests can be regarded as a kind of "time capsules". All these structures provide suitable habitats for a variety of species that are linked with cultural landscapes and manifold human activities [37, 55, 145, 146]. Concerning the herb-layer vegetation, however, these conditions can also lead to a more nutrient- and light-demanding, urbanophilic species composition as compared to publicly owned forests with a higher share of ancient-woodland species [19]. On the other hand, decades-long low management intensities in European small private forests have been found to result in
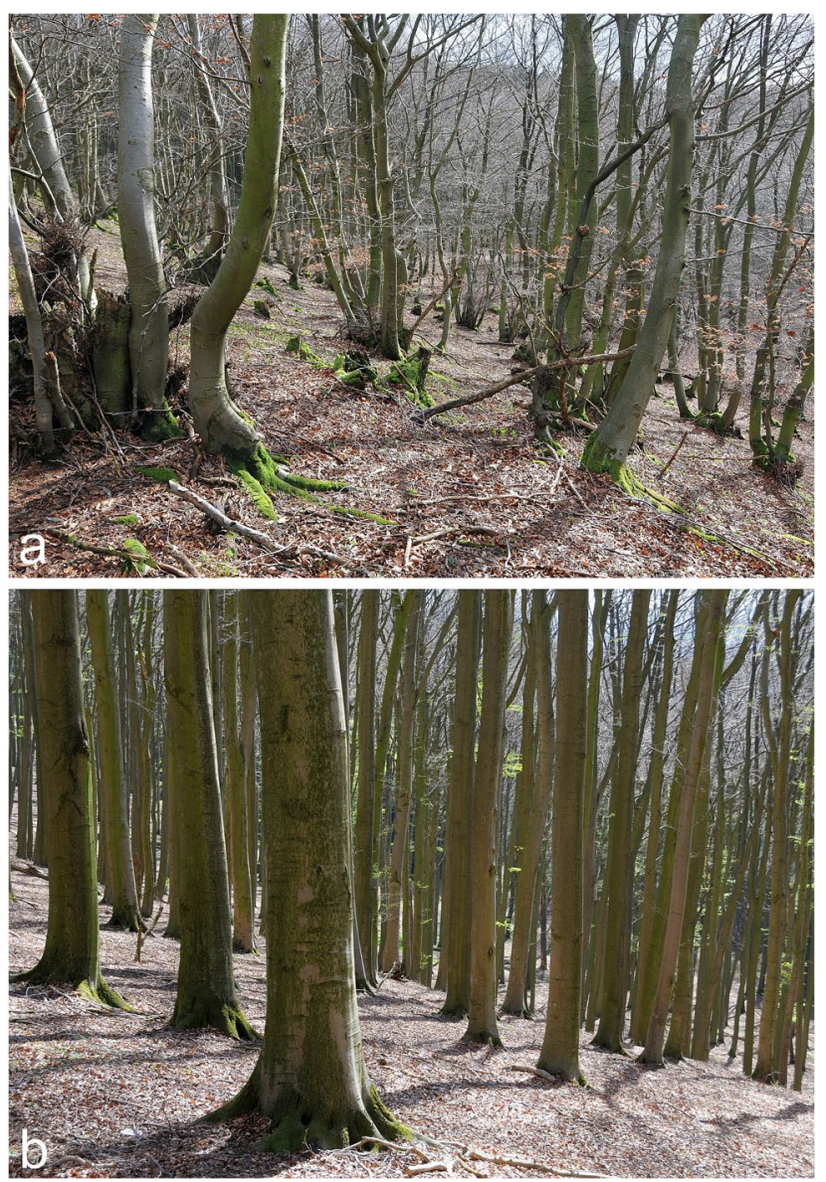

Fig. 2 Forest ownership shapes forest structure: Both beech (Fagus sylvatica) forest stands are growing on similar sites in close vicinity, but the coppice stand (a) is small private forest, and the high forest stand (b) is state forest. Teutoburg Forest, northwest Germany. Photos: Andreas Mölder

higher levels of structural diversity, more deadwood, greater carbon storage capacity [139], and a higher density of treerelated microhabitats [147] as compared to adjacent publicity owned and more intensively managed forests. It has been observed that an initial increase in the structural diversity of small private forests occurs quite quickly after management cessation $[128,130]$.

\section{Commonly Owned Forests}

Only one study by Holmgren et al. [148] included commonly owned forests into an ownership-type comparison. This study concluded that commonly owned forests in Sweden did not differ from the other forest ownership categories in terms of biodiversity indicators such as deadwood volume and the proportion of stands older than 140 years. Surprisingly, commonly owned forests have not been considered by more comparative studies in terms of ownership effects, since current research supports the idea that 
community-based management can hold useful insights for the maintenance of diverse ecosystems with great importance for biodiversity conservation [56•,149].

\section{Implications for Conservation Management in Mixed-Ownership Forest Landscapes}

Based on the findings of the two previous sections and taking into account further ownership-related studies identified by the literature review, we synthesize the main recommendations for conservation management and strategies in mixed-ownership forest landscapes. We have arranged these recommendations into four main groups (A-D) and six sub-groups (A.1-C.2) of related measures and strategies (i.e., implications) and compiled a stepwise framework of implications that build on one another (Fig. 3).

Landscape-wide forest conservation planning requires in most cases the consideration of more than a single forest ownership type. Mixed-ownership forest landscapes predominate in the temperate zones of Europe and North America, whereby the forestland belonging to different forest ownership types is spatially interwoven in different intensities [9, 22-24]. Therefore, cross-boundary ecosystem management (implication group $A$ ) is of crucial importance for addressing large-scale ecological issues in forested landscapes $[133,150,151,152 \bullet]$. In this context, we refer to the boundaries between the different ownership types.

Our literature review identified close linkages between ownership type-specific forest management and particular forest structural and biodiversity patterns in past and current times. According to these findings, mixed-ownership landscapes cover a more diverse mosaic of habitats compared to just one type of ownership. Such landscapes are typically lacking a wilderness-like degree of naturalness, but they are rich in a great variety of woodland habitats that are linked with cultural landscapes and manifold human activities. The management of these human-modified lands as "working landscapes" for the benefits of both people and biodiversity is a great challenge [153].

Given a landscape matrix of publicly owned and large and small private forests, management-related spatial complementary effects are to be expected since every ownership type contributes a distinct set of habitats and species to overall landscape biodiversity [20, 21, 117, 154]. In particular, forest types linked to private ownership, for example, diverse

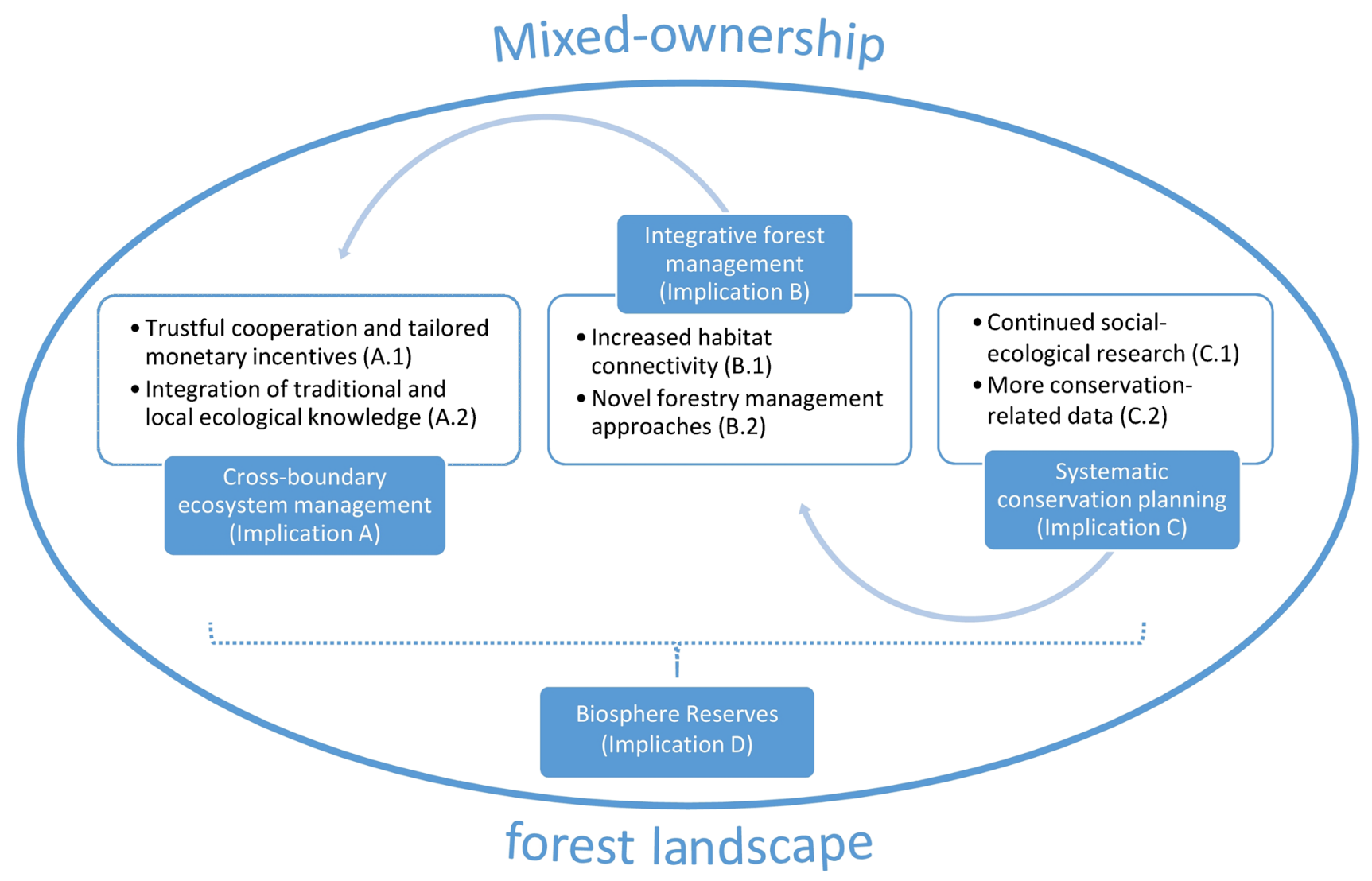

Fig. 3 Schematic representation of the 10 identified implications for conservation management in mixed-ownership forest landscapes that build on each other and may enhance cross-boundary ecosystem management. Filled blue boxes: summary implications that depend on previous steps 
young forests in North America [117, 133] or coppice forests in Europe [37, 55], can be frequently absent or poorly represented in public land. Vice versa, forest reserves and ancient woodland sites with a long continuity of consistent forest management appeared to be predominantly connected with public ownership [113, 125, 130]. Therefore, conservation planning and management at the landscape scale requires integrative forest management (implication group $B)$ that considers biodiversity and both social-ecological and economic aspects across ownerships [133]. The simple fact that forest habitats do not necessarily follow holding borders further emphasizes such need [23]. Integrative forest management, however, must take those habitat types and species of conservation concern into account that are specific for certain ownership types. Uniform management guidelines across ownership types should be prevented since they would result in both landscape homogenization and habitat loss and therefore counteract the above-mentioned spatial complementary effects. Additionally, the manifold objectives of forest owners are important sources and drivers for selecting the best (future) management approaches and should therefore be maintained-see the section on novel forestry management approaches below. Above all, an important requirement for both sustainable forestry and effective forest conservation management is tenure security and stability $[155,156]$.

In recent years, systematic conservation planning (implication group $C$ ) became a research field of its own that increasingly gained practical implementation in mixedownership forest landscapes as well [157•]. It can be applied to identify biodiversity hotspots, optimize the connection of otherwise fragmented habitats or endangered species populations, or perform representativity analyses of protected areas or habitat types within multi-ownership landscapes $[157 \bullet, 158]$. Advances in multivariate modeling allow identifying the best possible pathways to protect biodiversity, while at the same time minimizing costs [159••]. For these reasons, systematic conservation planning has great potential for promoting both integrative and effective conservation management in mixed-ownership forest landscapes [157• $160,161]$. In this context, continued social-ecological research (implication sub-group C.1) that considers both the evolution and the physical and social dynamics of multitenure reserve networks will inform improved conservation planning at the landscape scale [162]. The patterns of outdoor recreation have to be considered in this context as well [163]. For the successful implementation of systematic conservation planning, forestry and environmental data of comparable quality are required for all ownership types. This includes, in particular, data on species occurrences, conservation-relevant forest structures, and habitat distributions [78, 138, 164]. While these conservation-related data are available for most publicly owned or large private forests due to periodic inventories, they are often lacking for small private forests, given their small-sized structure and diverse owner objectives. For these reasons, case studies found higher conservation values than generally expected most notably in small private forests [55, 139, 143]. Consequently, more conservation-related data (implication sub-group C.2) from private land and better public access to existing forestry data are needed for effective conservation planning in mixed-ownership landscapes $[150,165]$. It has been highlighted, though, that publicly owned sites are essential elements of every conservation network [22] and that any removal of conservation measures on public land, for example, due to a policy change, could not be compensated by the current level of conservation efforts on private land [135]. Developing sustainability units of ecological continuity [34] or evidence-based improvement of the reserve network $[154,159 \bullet \bullet]$ are exemplary approaches of how to generate concrete systematic conservation planning outcomes in mixed-ownership landscapes. Increased retention forestry [160] and the development of networks of unmanaged micro-reserves for the conservation of saproxylic species that are connected by corridors of habitat trees and deadwood $[158,166]$ are additional application areas for systematic conservation planning. Such approaches to increased habitat connectivity (implication sub-group B.1) that promote the movement of organisms, natural processes, and ecosystem services are crucial for effective conservation management in working landscapes [141, 153, 160].

Many small-scale private forest owners increasingly focus their management on other (cultural) ecosystem services than only wood production [93••, 140, 141, 167]. This paradigm shift is an opportunity to implement integrative novel forestry management approaches (implication subgroup $B .2$ ) that consider the motivations, attitudes, and behaviors of the new forest owner types. Such approaches include management for non-timber products and services, measures for maintaining stable forest stands at low costs, or new types of cooperative forestry [93••]. As illustrated above, conservation values in small private forests particularly depend on stand structures and habitat mosaics that are caused by a diversity of management approaches and intensities. Hence, a wide range of novel forestry management approaches offers a great chance to maintain such habitat mosaics in the future. It has to be kept in mind, however, that changes in ecosystem services and biodiversity resulting from forest landowners' climate adaptation behavior may occur $[168,169]$.

Particularly in mixed-ownership landscapes, effective conservation management depends on motivated landowners who support and recognize the aims of conservation [26•]. In addition to trustful cooperation between the different types of forest owners and both conservation and forestry agencies [103, 152•, 170, 171], tailored monetary incentives 
(implication sub-group A.1) for conservation efforts such as habitat-tree retention, the re-establishment of historical forest management techniques, or natural forest development are necessary. Payment schemes that are targeting cross-boundary ecosystem management and are adapted to the different ownership types seem necessary. For private forests, for instance, contract-based nature conservation is a suitable approach [103, 172, 173].

To maintain local management approaches and mosaics that shape forest structures and habitats of conservation concern, the integration of traditional and local ecological knowledge (implication sub-group A.2) into the conservation management of mixed-ownership forest landscapes is necessary. Such efforts are most likely to be successful if the knowledge holders are directly engaged as active participants [131, 141, 174]. For example, the traditional expertise of European local farmers on coppice management can provide a suitable base for the re-establishment of this forest management technique [61]. Concerning North America, traditional knowledge of Native Americans provides important information for managing forest habitats of conservation concern $[175,176]$. Given these considerations, the designation of Biosphere Reserves (implication group D) provides a possible framework for holistically integrating effective conservation management in mixed-ownership landscapes. Biosphere Reserves are a mechanism within the UNESCO Man and the Biosphere Program (MAB) providing an approach to land management that harmonizes interactions between people and nature. The conceptual model behind the Biosphere Reserves idea is based on integrated management across a landscape through an approach to zonation of core, buffer, and transition zones to harmonize conservation and development [177]. Concerning the core studies listed in Table 1 and Online Resource B, those by Schaich and Plieninger [139], Johann and Schaich [147], and LovettDoust and Kuntz [22] have been conducted in Biosphere Reserves in Germany and Canada, respectively. However, not every region with mixed-ownership forest landscapes is suitable to be designated as a Biosphere Reserve, and an expansion of this conservation scheme to all forests is unrealistic, particularly in densely populated working landscapes. Again, it is systematic conservation planning that provides suitable methods for decision-making.

\section{Conclusions}

As stated in the introduction, we are aware that a literature review on the interplay of forest ownership patterns, biodiversity, and conservation management is a great challenge and that some aspects remained unconsidered or relationships may deviate at regional scales. Particularly due to the limited number of 22 studies that have analyzed the relationships between forest ownership patterns and both forest structural and biodiversity patterns in present mixedownership landscapes, geographic variation within Europe and North America may not be sufficiently considered.

Despite these limitations, however, we were able to point out close linkages between ownership type-specific forest management and particular forest structural and biodiversity patterns in past and current forest landscapes. Both in Europe and North America, publicly and privately owned forests showed comparable lines of development in the late modern period. This is particularly true concerning welldefined management plans in the state and large private forests and both fragmentation and a high diversity of management approaches in small private forests. There were, however, time shifts concerning the onset of these developments: Scientific forestry was introduced to North America at the end of the nineteenth century, around 150 years later than in Europe. Forest fragmentation and the parcelization of private forest ownership into even smaller ownerships became significant issues in North America from the early twentieth century onwards and about 100 to 150 years later than in Europe. We think that these results provide an impetus for further research on ownership-biodiversity interactions also in other parts of the world. Such future studies should also closely consider the effects of the physical environment on the development of ownership structures and the related forest structural and biodiversity patterns.

Our review confirmed that forest reserves and ancient woodland sites with both a pronounced ecological continuity and a long continuity of consistent forest management appear to be predominantly connected with public ownership. Vice versa, forest types and habitats linked to private ownership are absent or poorly represented in public land, for example, diverse young forests in western North America. Remnants of historical forest management practices, such as coppicing, also have a close connection to smallscale private forest ownership in Europe and are typically scant in publicly owned forests.

Following these findings, a more diverse mosaic of habitats has developed in many mixed-ownership landscapes than would be the case with just one type of ownership. This is particularly true for a great variety of forest habitats that are linked with cultural landscapes and manifold human activities. However, our review revealed the relative scarcity of studies that analyze the relationships between ownershiprelated effects and both forest structural and biodiversity patterns in mixed-ownership landscapes. We would like to encourage researchers to conduct further studies on this topic in a variety of regions, also in consideration of common, tribal, or indigenous forest ownership. The diversity of community forest arrangements in Europe [28 $\bullet$ provides many possibilities for studies that compare their structures and conservation values with forests held by other ownership 
types. Furthermore, also the analysis of ownership-related effects on the distribution of endangered or invasive plant and animal species would be useful. The same is true for studying the relationships between ownership patterns and natural disturbances such as wildfires [134, 178], especially concerning the effects of climate change.

Ecosystem management across ownership boundaries is of crucial importance concerning effective conservation schemes in present-day mixed-ownership landscapes. Such far-sighted conservation planning at the landscape scale requires integrative management that considers biodiversity and both social-ecological and economic aspects across ownership types. Integrative forest management, however, must take those habitat types and species of conservation concern into account that are specific for certain ownership types. Uniform management guidelines across ownership types should be prevented since they would result in both landscape homogenization and habitat loss. Hence, further studies are needed that develop appropriate novel forestry management approaches for mixed-ownership landscapes, especially in view of new forest owner types and climate change effects.

Supplementary Information The online version contains supplementary material available at https://doi.org/10.1007/s40725-021-00143-w.

Acknowledgements We are indebted to three anonymous reviewers for suggestions that greatly improved the article.

Author Contribution A.M. has designed and performed the literature review and wrote the manuscript together with M.T. and T.P. All authors discussed the results and commented on the manuscript.

Funding This study is part of the research project "Small private forests: conservation through resource use" (KLEIBER). The KLEIBER project receives financial support from the German Federal Ministry of Food and Agriculture (BMEL) through the Agency of Renewable Resources (FNR) within the funding program "Renewable Resources" and according to a decision of the German Parliament (FKZ 22001218 and 22023218). Open Access funding was enabled and organized by Projekt DEAL.

Availability of Data and Material Data sharing is not applicable to this review article as no numerical datasets were generated or analyzed during the current study.

Code Availability Not applicable.

\section{Declarations}

Conflict of Interest The authors declare that they have no conflict of interest.

Human and Animal Rights and Informed Consent This article does not contain any studies with human or animal subjects performed by any of the authors.
Open Access This article is licensed under a Creative Commons Attribution 4.0 International License, which permits use, sharing, adaptation, distribution and reproduction in any medium or format, as long as you give appropriate credit to the original author(s) and the source, provide a link to the Creative Commons licence, and indicate if changes were made. The images or other third party material in this article are included in the article's Creative Commons licence, unless indicated otherwise in a credit line to the material. If material is not included in the article's Creative Commons licence and your intended use is not permitted by statutory regulation or exceeds the permitted use, you will need to obtain permission directly from the copyright holder. To view a copy of this licence, visit http://creativecommons.org/licenses/by/4.0/.

\section{References}

Papers of particular interest, published recently, have been highlighted as:

- Of importance

• Of major importance

1. Mayer AL, Tikka PM. Biodiversity conservation incentive programs for privately owned forests. Environ Sci Pol. 2006;9:614-25.

2. Zammit C. Landowners and conservation markets: social benefits from two Australian government programs. Land Use Pol. 2013;31:11-6.

3. Drescher M, Warriner GK, Farmer JR, Larson BMH. Private landowners and environmental conservation: a case study of socialpsychological determinants of conservation program participation in Ontario. Ecol Soc. 2017;22:44.

4. Borrass L, Kleinschmit D, Winkel G. The "German model" of integrative multifunctional forest management - analysing the emergence and political evolution of a forest management concept. For Policy Econ. 2017;77:16-23.

5. Feliciano D, Bouriaud L, Brahic E, Deuffic P, Dobsinska Z, Jarsky V, et al. Understanding private forest owners' conceptualisation of forest management: evidence from a survey in seven European countries. J Rural Stud. 2017;54:162-76.

6. Sotirov M, Sallnas O, Eriksson LO. Forest owner behavioral models, policy changes, and forest management. An agentbased framework for studying the provision of forest ecosystem goods and services at the landscape level. For Policy Econ. 2019;103:79-89.

7. Weiss G, Lawrence A, Lidestav G, Feliciano D, Hujala T, Sarvasova Z, et al. Research trends: forest ownership in multiple perspectives. For Policy Econ. 2019;99:1-8.

8. Balukas JA, Bell KP, Bauer DM. Classifying private landowners to improve understanding of management decisions and conservation opportunities in urbanizing forested landscapes. J Environ Manage. 2019;232:751-8.

9. Stanfield BJ, Bliss JC, Spies TA. Land ownership and landscape structure: a spatial analysis of sixty-six Oregon (USA) Coast Range watersheds. Landsc Ecol. 2002;17:685-97.

10. Li Y-H, Wu W, Li N-N, Bu R-C, Hu Y-M. Effects of forest ownership regime on landscape pattern and animal habitat: a review. Chin J Appl Ecol. 2013;24:2056-62.

11. Porto M, Correia O, Beja P. Optimization of landscape services under uncoordinated management by multiple landowners. PLoS One. 2014;9:e86001.

12. Braithwaite W, Belbin L, Ive J, Austin M. Land use allocation and biological conservation in the Batemans Bay Forests of New South Wales. Austral For. 1993;56:4-21. 
13. McCay DH. Effects of chronic human activities on invasion of longleaf pine forests by sand pine. Ecosystems. 2000;3:283-92.

14. McClellan M, Montgomery R, Nelson K, Becknell J. Comparing forest structure and biodiversity on private and public land: secondary tropical dry forests in Costa Rica. Biotropica. 2018;50:510-9.

15. $\bullet$ Easterday K, McIntyre P, Kelly M. Land ownership and 20th century changes to forest structure in California. For Ecol Manage. 2018;422:137-46 This very informative paper investigates long-term changes to forest structure across six land ownership classes in California. Historical and contemporary forest structural data are thoroughly analyzed.

16. Shell AB, Ojha SK, Sharma A. Region-wide characterization of structural diversity of the U.S. Outer Coastal Plain Mixed Forests Province. For Ecol Manage. 2021;488:118979.

17. Mwase WF, Bjørnstad Å, Bokosi JM, Kwapata MB, Stedje $B$. The role of land tenure in conservation of tree and shrub species diversity in miombo woodlands of southern Malawi. New For. 2007;33:297-307.

18. Li N-N, Li Y-H. Management modes of different ownership forests and their ecological effects: a review. Chin J Appl Ecol. 2011;22:1623-31.

19. Bergès L, Avon C, Verheyen K, Dupouey J-L. Landownership is an unexplored determinant of forest understory plant composition in Northern France. For Ecol Manage. 2013;306:281-91.

20. Marinaro S, Grau HR, Macchi L, Zelaya PV. Land tenure and biological communities in dry Chaco forests of northern Argentina. J Arid Environ. 2015;123:60-7.

21. Hobart BK, Roberts KN, Dotters BP, Berigan WJ, Whitmore SA, Raphael MG, et al. Site occupancy and reproductive dynamics of California spotted owls in a mixed-ownership landscape. For Ecol Manage. 2019;437:188-200.

22. Lovett-Doust J, Kuntz K. Land ownership and other landscape-level effects on biodiversity in southern Ontario's Niagara Escarpment Biosphere Reserve, Canada. Landsc Ecol. 2001;16:743-55.

23. Kurttila M, Uuttera J, Mykrä S, Kurki S, Pukkala T. Decreasing the fragmentation of old forests in landscapes involving multiple ownership in Finland: economic, social and ecological consequences. For Ecol Manage. 2002;166:69-84.

24. Reise J, Kukulka F, Flade M, Winter S. Characterising the richness and diversity of forest bird species using National Forest Inventory data in Germany. For Ecol Manage. 2019;432:799-811.

25. $\bullet U N E C E$, FAO, editors. Who owns our forests? Forest ownership in the ECE region. Geneva: ECE; 2020. This thorough and elucidating study is based on data from 33 European countries, the U.S., and Canada. Considering all categories of forest ownership, the ways in which governance and social structures influence forest owners, users, and forest management are analyzed.

26. $\bullet$ Mayer AL. Family forest owners and landscape-scale interactions: a review. Landsc Urban Plan. 2019;188:4-18 A comprehensive and informative review of worldwide literature.

27. Zhang Y, Zhang D, Schelhas J. Small-scale non-industrial private forest ownership in the United States: rationale and implications for forest management. Silva Fenn. 2005;39:443-54.

28. Lawrence A, Gatto P, Bogataj N, Lidestav G. Forests in common: learning from diversity of community forest arrangements in Europe. Ambio. 2021;50:448-64 A careful analysis of community forest arrangements in Italy, Scotland, Slovenia, and Sweden.

29. Szabó P, Hédl R. Advancing the integration of history and ecology for conservation. Conserv Biol. 2011;25:680-7.
30. Raum S. Land-use legacies of twentieth-century forestry in the UK: a perspective. Landsc Ecol. 2020;35:2713-22.

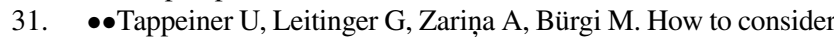
history in landscape ecology: patterns, processes, and pathways. Landscape Ecol. 2021;36:2317-28 A sound introduction to the emerging research field of historical landscape ecology.

32. Bergès L, Dupouey J-L. Historical ecology and ancient forests: progress, conservation issues and scientific prospects, with some examples from the French case. J Veg Sci. 2021;32:e12846.

33. Ammer C, Fichtner A, Fischer A, Gossner MM, Meyer P, Seidl $\mathrm{R}$, et al. Key ecological research questions for Central European forests. Basic Appl Ecol. 2018;32:3-25.

34 Mölder A, Meyer P, Nagel R-V. Integrative management to sustain biodiversity and ecological continuity in Central European temperate oak (Quercus robur, Q. petraea) forests: an overview. For Ecol Manage. 2019;437:324-39.

35 Vandekerkhove K, Baeté H, Van Der Aa B, De Keersmaeker L, Thomaes A, Leyman A, et al. 500 years of coppice-with-standards management in Meerdaal Forest (Central Belgium). iForest. 2016;9:509-17.

36. Larrieu L, Cabanettes A, Gouix N, Burnel L, Bouget C, Deconchat M. Development over time of the tree-related microhabitat profile: the case of lowland beech-oak coppicewith-standards set-aside stands in France. Eur J For Res. 2017;136:37-49.

37. Unrau A, Becker G, Spinelli R, Lazdina D, Magagnotti N, Nicolescu V-N, et al., editors. Coppice forests in Europe. Freiburg: Albert Ludwig University; 2018.

38. Pfadenhauer JS, Klötzli F. Global vegetation: fundamentals, ecology and distribution. Cham: Springer; 2020.

39. UNEP-WCMC. Protected area profile for Europe from the World Database of Protected Areas. 2021. Available from: www.prote ctedplanet.net. Accessed 25 Apr 2021.

40. Directorate-General for Environment. Natura 2000 barometer. Nat Biodivers Newsl. 2020;49:8-9.

41. European Commission. Natura 2000 and Forests, Part I-II. Luxembourg: Publications Office of the EU; 2015.

42. UNEP-WCMC. Protected area profile for the United States of America from the World Database of Protected Areas. 2021. Available from: www.protectedplanet.net. Accessed 25 Apr 2021.

43. UNEP-WCMC. Protected area profile for Canada from the World Database of Protected Areas. 2021. Available from: www.prote ctedplanet.net. Accessed 25 Apr 2021.

44. Seidensticker A. Waldgeschichte des Alterthums. Zweiter Band. Nach Cäsar [Forest History of Antiquity. Second volume. After Caesar]. Frankfurt a. O.: Trowitzsch und Sohn; 1886.

45. Sedlar JW. East Central Europe in the Middle Ages, 1000-1500. Washington, D.C.: University of Washington Press; 1994.

46. Verhulst A. The Carolingian economy. Cambridge: Cambridge University Press; 2002.

47. Langton J. Royal and non-royal forests and chases in England and Wales. Hist Res. 2015;88:381-401.

48. Erbprinz von Leiningen EC. Schreiben Sr. Durchlaucht des Herrn Erbprinzen von Leiningen an den Herausgeber, die deutschen Urwälder betreffend [Letter to the editor concerning the German virgin forests]. In: Wildungen LCEHF von, editor. Taschenbuch für Forst- und Jagdfreunde für das Jahr 1803 und 1804. Marburg: Neue akademische Buchhandlung; 1803. p. 124-32.

49. Heurich M, Engelmaier KH. The development of tree species composition in the Rachel-Lusen region of the Bavarian Forest National Park. Silva Gabreta. 2010;16:165-86.

50. McGranahan G. Fuelwood, subsistence foraging, and the decline of common property. World Dev. 1991;19:1275-87. 
51. Fritzbøger B. "A Windfall for the Magnates" - The development of woodland ownership in Denmark c. 1150-1830. Odense: University Press of Southern Denmark; 2004.

52. Montiel MC. Cultural heritage, sustainable forest management and property in inland Spain. For Ecol Manage. 2007;249:80-90.

53. van Gils H, Siegl G, Mark BR. The living commons of West Tyrol, Austria: lessons for land policy and land administration. Land Use Pol. 2014;38:16-25.

54. Paletto A, Meo ID, Cantiani P, Ferretti F. Effects of forest management on the amount of deadwood in Mediterranean oak ecosystems. Ann For Sci. 2014;71:791-800.

55 Mölder A. Small forest parcels, management diversity and valuable coppice habitats: an 18th century political compromise in the Osnabrück region (NW Germany) and its long-lasting legacy. iForest. 2016;9:518-28.

56. •Guadilla-Sáez S, Pardo-de-Santayana M, Reyes-García V. Forest commons, traditional community ownership and ecological consequences: insights from Spain. For Policy Econ. 2020;112:102107 By examining the historical evolution of collective property regimes in Spain, this paper explores how local forms of traditional community forest use and governance contribute to biodiversity conservation.

57. Szabó P, Hédl R. Socio-economic demands, ecological conditions and the power of tradition: past woodland management decisions in a Central European landscape. Landsc Res. 2013;38:243-61.

58. Overton M. Agricultural revolution in England: the transformation of the agrarian economy, 1500-1850. Cambridge: Cambridge University Press; 1996.

59. Meyer P, Janda P, Mikoláš M, Trotsiuk V, Krumm F, Mrhalová $\mathrm{H}$, et al. A matter of time: self-regulated tree regeneration in a natural Norway spruce (Picea abies) forest at Mt. Brocken, Germany. Eur J For Res. 2017;136:907-21.

60. Müllerová J, Szabó P, Hédl R. The rise and fall of traditional forest management in southern Moravia: a history of the past 700 years. For Ecol Manage. 2014;331:104-15.

61 Johann E. Coppice forests in Austria: the re-introduction of traditional management systems in coppice forests in response to the decline of species and landscape and under the aspect of climate change. For Ecol Manage. 2021;490:119129.

62. Clapham JH. The economic development of France and Germany: 1815-1914. 3rd ed. Cambridge: Cambridge University Press; 1928.

63. Duma P, Latocha A, Łuczak A, Piekalski J. Stone walls as a characteristic feature of the cultural landscape of the Izera Mountains, southwestern Poland. Int J Hist Archaeol. 2019;24:22-43.

64. Farrell EP, Führer E, Ryan D, Andersson F, Hüttl R, Piussi P. European forest ecosystems: building the future on the legacy of the past. For Ecol Manage. 2000;132:5-20.

65. McGrath MJ, Luyssaert S, Meyfroidt P, Kaplan JO, Bürgi M, Chen Y, et al. Reconstructing European forest management from 1600 to 2010. Biogeosciences. 2015;12:4291-316.

66. Ford C. Nature, culture and conservation in France and her colonies 1840-1940. Past Present. 2004;183:173-98.

67. Hopkinson AD. The state forests of Saxony. Trans R Scot Arbor Soc. $1913 ; 27 ; 28: 174-87 ; 28-46$.

68. Bürgi M, Schuler A. Driving forces of forest management - an analysis of regeneration practices in the forests of the Swiss Central Plateau during the 19th and 20th century. For Ecol Manage. 2003;176:173-83.

69. Eliasson P, Nilsson SG. 'You should hate young oaks and young noblemen': the environmental history of oaks in eighteenth- and nineteenth-century Sweden. Environ Hist. 2002;7:659-74.
70. Bobiec A, Reif A, Öllerer K. Seeing the oakscape beyond the forest: a landscape approach to the oak regeneration in Europe. Landsc Ecol. 2018;33:513-28.

71. Grove SJ. Saproxylic insect ecology and the sustainable management of forests. Annu Rev Ecol Syst. 2002;33:1-23.

72. Conwentz H. On national and international protection of nature. J Ecol. 1914;2:109-22.

73. Vivier N. Propriété collective et identité communale: les biens communaux en France 1750-1914 [Collective property and communal identity. Communal goods in France, 1750-1914]. Paris: Publications de la Sorbonne; 1998.

74. Brakensiek S. Agrarian individualism in north-western Germany, 1770-1870. German Hist. 1994;12:137-79.

75. Nonic D, Bliss JC, Milijic V, Petrovic N, Avdibegovic M, Mataruga M. Challenges of organizing private forest owners in Serbia. Small-scale For. 2011;10:435.

76. Mairota P. Legislation abolishing feudalism and its consequences on landownership structure in southern Italy. Mediterranean Desertification and Land Use (MEDALUS) Working Paper Series. 1995;62:2-12.

77. Maltamo M, Uuttera J, Kuusela K. Differences in forest stand structure between forest ownership groups in central Finland. J Environ Manage. 1997;51:145-67.

78. von Lüpke N, Hardtke A, Lück M, Hessenmöller D, Ammer C, Schulze E-D. Bestandesvorrat, Baumartenvielfalt und Struktur kleinparzellierter Privatwälder im Hainich [Growing stock, diversity of tree species and structure of stripped private-owned forests in the Hainich region, Thuringia, Germany]. Forstarchiv. 2011;82:203-15.

79. Andrieu E, Ladet S, Heintz W, Deconchat M. History and spatial complexity of deforestation and logging in small private forests. Landsc Urban Plan. 2011;103:109-17.

80. Balent G. La forêt paysanne dans l'espace rural: biodiversité, paysages, produits [Farm forests in rural areas: biodiversity, landscapes, products. Studies and research on agrarian systems and development]. Études et Recherches sur les Systèmes Agraires et le Développement. 1996;29:1-268.

81. Read H, Bengtsson V, Castro A, Harris R, Wheater CP. Restoration of lapsed beech pollards in the Basque region of Spain: comparison of different cutting techniques. Arboric J. 2021; https://doi.org/10.1080/03071375.2020.1854993

82. Marsh GP. Man and nature; or, physical geography as modified by human action. New York: C. Scribner; 1865 .

83. Wäldchen J, Schulze ED, Mund M, Winkler B. Der Einfluss politischer, rechtlicher und wirtschaftlicher Rahmenbedingungen des 19. Jahrhunderts auf die Bewirtschaftung der Wälder im Hainich-Dün-Gebiet (Nordthüringen) [Forest management in the Hainich Dün region (northern Thuringia) during the 19th century under political, juridical and economic changes]. Forstarchiv. 2011;82:35-47.

84. Conwentz H. Fürstlich Hohenzollernsches Naturschutzgebiet im Böhmerwald [Princely Hohenzollern nature reserve in the Bohemian Forest]. J Ecol. 1913;1:161-6.

85. Vrška T, Hort L. Historie vzniku lesních rezervací v ČR do roku 1945 [The development history of forest reserves in the Czech Republic until 1945]. Ochrana Př́rody. 2008;63:8-10.

86. Mölder A, Gürlich S, Engel F. Die Verbreitung von gefährdeten Holz bewohnenden Käfern in Schleswig-Holstein unter dem Einfluss von Forstgeschichte und Besitzstruktur [The distribution of endangered saproxylic beetles in Schleswig-Holstein (Northern Germany) as influenced by historic land use and land tenure patterns]. Forstarchiv. 2014;85:84-101.

87. Gowdy JT. World Forestry: forestry in the German Democratic Republic. J For. 1980;78:283-4. 
88. Plieninger T, Schaich H. Socialist and postsocialist land-use legacies determine farm woodland composition and structure: lessons from Eastern Germany. Eur J For Res. 2014;133:597-610.

89. Munteanu C, Nita MD, Abrudan IV, Radeloff VC. Historical forest management in Romania is imposing strong legacies on contemporary forests and their management. For Ecol Manage. 2016;361:179-93.

90. Zelinka V. Continuity and extinction of agricultural land in the Sudetes - a case study in the landscape of highlands and mountains. J Landsc Ecol. 2018;11:53-66.

91. Jaroszyk-Pawlukiewicz J. Transfer of ownership of forests in the western and northern territories after World War II: nationalization and reprivatization. Stud Hist Oecon. 2018;36:125-41.

92. Kuemmerle T, Kozak J, Radeloff VC, Hostert P. Differences in forest disturbance among land ownership types in Poland during and after socialism. J Land Use Sci. 2009;4:73-83.

93. $\bullet$ Weiss G, Lawrence A, Hujala T, Lidestav G, Nichiforel L, Nybakk E, et al. Forest ownership changes in Europe: state of knowledge and conceptual foundations. For Policy Econ. 2019;99:9-20 This thorough paper on forest ownership changes in Europe provides an overview of the state of knowledge, discusses relevant issues, and provides conceptual and practical foundations for future research, forest management approaches, and policy making.

94. Williams M. Americans and their forests: a historical geography. Cambridge: Cambridge University Press; 1992.

95. Delcourt PA, Haccou P, Delcourt PA, Delcourt HR. Prehistoric Native Americans and ecological change: human ecosystems in eastern North America since the Pleistocene. Cambridge: Cambridge University Press; 2004.

96. Isakson HR, Sproles S. A brief history of Native American land ownership. In: Simons RA, Malmgren R, Small G, editors. Indigenous Peoples and real estate valuation. Boston: Springer US; 2008. p. 63-75.

97. Brose P, Schuler T, van Lear D, Berst J. Bringing fire back: the changing regimes of the Appalachian mixed-oak forests. J For. 2001;99:30-5.

98. Abrams MD, Nowacki GJ. Native Americans as active and passive promoters of mast and fruit trees in the eastern USA. Holocene. 2008;18:1123-37.

99. Zimmerman E. A historical summary of state and private forestry in the U.S. Forest Service. Washington, D.C.: U.S. Department of Agriculture, Forest Service, State and Private Forestry; 1976.

100. Foster DR. Land-use history (1730-1990) and vegetation dynamics in central New England, USA. J Ecol. 1992;80:753-71.

101. Michaux FA. The North America Sylva, or a description of the forest trees of the United States, Canada and Nova Scotia. Paris: D'Hautel; 1819.

102. Wiens JA, Hayward GD, Safford HD, Giffen C. Historical environmental variation in conservation and natural resource management. Chichester: Wiley; 2012.

103. Meyer SR, Cronan CS, Lilieholm RJ, Johnson ML, Foster DR. Land conservation in northern New England: historic trends and alternative conservation futures. Biol Conserv. 2014;174:152-60.

104. Gillis RP, Roach TR. The American influence on conservation in Canada: 1899-1911. J For Hist. 1986;30:160-74.

105. Larsen JA. Carl Alwin Schenck and the Biltmore Forest. Ames Forester. 1961;48:15-9.

106. Kennedy RSH, Spies TA. Forest cover changes in the Oregon Coast Range from 1939 to 1993. For Ecol Manage. 2004;200:129-47.

107. Franklin JF, Donato DC. Variable retention harvesting in the Douglas-fir region. Ecol Process. 2020;9:8.
108. Poore D. Forestry and nature conservation: changing perspectives. Commonw For Rev. 1995;74:5-19.

109. Gustafsson L, Baker SC, Bauhus J, Beese WJ, Brodie A, Kouki $\mathrm{J}$, et al. Retention forestry to maintain multifunctional forests: a world perspective. Bioscience. 2012;62:633-45.

110. Brooks RT. Abundance, distribution, trends, and ownership patterns of early-successional forests in the northeastern United States. For Ecol Manage. 2003;185:65-74.

111. Davis MB. Eastern old-growth forests: prospects for rediscovery and recovery. Washington, D. C. and Covelo: Island Press; 1996.

112. Bouman OT, Vaninetti N, Williams GEM, McCorquodale DB. Ecological and historical evidence of anthropogenic forest transformations in eastern Cape Breton Island. J Sustain For. 2005;19:49-76.

113. Riitters KH, Coulston JW, Wickham JD. Fragmentation of forest communities in the eastern United States. For Ecol Manage. 2012;263:85-93.

114. Crow TR, Host GE, Mladenoff DJ. Ownership and ecosystem as sources of spatial heterogeneity in a forested landscape, Wisconsin, USA. Landsc Ecol. 1999;14:449-63.

115. Litvaitis JA. Response of early successional vertebrates to historic changes in land use. Conserv Biol. 1993;7:866-73.

116. Stein SM, McRoberts RE, Nelson MD, Mahal L, Flather CH, Alig RJ, et al. Private forest habitat for at-risk species: where is it and where might it be changing? J For. 2010;108:61-70.

117. Maslo B, Lockwood JL, Leu K. Land ownership patterns associated with declining forest birds: targeting the right policy and management for the right birds. Environ Conserv. 2015;42:216-26.

118. McCune JL, Van Natto A, MacDougall AS. The efficacy of protected areas and private land for plant conservation in a fragmented landscape. Landscape Ecol. 2017;32:871-82.

119. DeCoster LA. The boom in forest owners - a bust for forestry? J For. 1998;96:25-8.

120. Radeloff VC, Hammer RB, Stewart SI. Rural and suburban sprawl in the U.S. Midwest from 1940 to 2000 and its relation to forest fragmentation. Conserv Biol. 2005;19:793-805.

121. Gustafson EJ, Loehle C. Effects of parcelization and land divestiture on forest sustainability in simulated forest landscapes. For Ecol Manage. 2006;236:305-14.

122. Mehmood SR, Zhang D. Forest parcelization in the United States: a study of contributing factors. J For. 2001;99:30-4.

123. Kittredge DB, Mauri MJ, McGuire EJ. Decreasing woodlot size and the future of timber sales in Massachusetts: when is an operation too small? N J Appl For. 1996;13:96-101.

124. Black AE, Morgan P, Hessburg PF. Social and biophysical correlates of change in forest landscapes of the interior Columbia Basin, USA. Ecol Appl. 2003;13:51-67.

125. Zheng D, Heath LS, Ducey MJ, Butler B. Relationships between major ownerships, forest aboveground biomass distributions, and landscape dynamics in the New England region of USA. Environ Manage. 2010;45:377-86.

126. Żmihorski M, Chylarecki P, Rejt $€$, Mazgajski TD. The effects of forest patch size and ownership structure on tree stand characteristics in a highly deforested landscape of central Poland. Eur J For Res. 2009;129:393-400.

127. Kennedy RSH, Spies TA, Gregory MJ. Relationships of dead wood patterns with biophysical characteristics and ownership according to scale in Coastal Oregon, USA. Landsc Ecol. 2008;23:55-68.

128. Torras O, Gil-Tena A, Saura S. Changes in biodiversity indicators in managed and unmanaged forests in NE Spain. J For Res. 2012;17:19-29.

129. Bujoczek L, Bujoczek M, Zięba S. How much, why and where? Deadwood in forest ecosystems: the case of Poland. Ecol Indic. 2021;121:107027. 
130. Rendenieks Z, Nikodemus O, Brūmelis G. The implications of stand composition, age and spatial patterns of forest regions with different ownership type for management optimisation in northern Latvia. For Ecol Manage. 2015;335:216-24.

131. Parviainen J. Cultural heritage and biodiversity in the present forest management of the boreal zone in Scandinavia. J For Res. 2015;20:445-52.

132. Thomas RC, Kirby KJ, Reid CM. The conservation of a fragmented ecosystem within a cultural landscape - the case of ancient woodland in England. Biol Conserv. 1997;82:243-52.

133. Ohmann JL, Gregory MJ, Spies TA. Influence of environment, disturbance, and ownership on forest vegetation of coastal Oregon. Ecol Appl. 2007;17:18-33.

134. Stephens CW, Collins BM, Rogan J. Land ownership impacts post-wildfire forest regeneration in Sierra Nevada mixed-conifer forests. For Ecol Manage. 2020;468:118161.

135. Suzuki N, Olson DH. Options for biodiversity conservation in managed forest landscapes of multiple ownerships in Oregon and Washington, USA. Biodivers Conserv. 2007;16:3895-917.

136. Swanson ME, Franklin JF, Beschta RL, Crisafulli CM, DellaSala DA, Hutto RL, et al. The forgotten stage of forest succession: early-successional ecosystems on forest sites. Front Ecol Environ. 2011;9:117-25.

137. Hanberry BB, Thompson FR. Open forest management for early successional birds. Wildl Soc Bull. 2019;43:141-51.

138. Deconchat M, Balent G. Vegetation and bird community dynamics in fragmented coppice forests. Forestry. 2001;74:105-18.

139. Schaich $\mathrm{H}$, Plieninger T. Land ownership drives stand structure and carbon storage of deciduous temperate forests. For Ecol Manage. 2013;305:146-57.

140. Snyder SA, Butler BJ, Markowski-Lindsay M. Small-area family forest ownerships in the USA. Small-scale For. 2019;18:127-47.

141. Joa B, Schraml U. Conservation practiced by private forest owners in Southwest Germany - the role of values, perceptions and local forest knowledge. For Policy Econ. 2020;115:102141.

142 Du Bus de Warnaffe G, Deconchat M, Ladet S, Balent G. Variability of cutting regimes in small private woodlots of southwestern France. Ann For Sci. 2006;63:915-27.

143. Wulf M, Kolk J. Plant species richness of very small forests related to patch configuration, quality, heterogeneity and history. J Veg Sci. 2014;25:1267-77.

144. Huston MA. Biological diversity: the coexistence of species. Cambridge: Cambridge University Press; 1994.

145. Pott R. Der Einfluß der Niederholzwirtschaft auf die Physiognomie und die floristisch-soziologische Struktur von Kalkbuchenwäldern [The influence of coppicing on the physiognomy and phytosociological structure of calcareous beechwoods]. Tuexenia. 1981;1:233-42.

146. Sourdril A, Andrieu E, Cabanettes A, Elyakime B, Ladet S. How to maintain domesticity of usages in small rural forests? Lessons from forest management continuity through a French case study. Ecol Soc. 2012;17:6.

147. Johann F, Schaich H. Land ownership affects diversity and abundance of tree microhabitats in deciduous temperate forests. For Ecol Manage. 2016;380:70-81.

148. Holmgren L, Holmgren E, Fridman J, Lidestav G. Biological diversity indicators: a comparison of Swedish forest commons and other forest ownership categories. Scand J For Res. 2010;25:61-8.

149. Mosandl R, Summa J, Stimm B. Coppice-with-standards: management options for an ancient forest system. For Ideas. 2010;16:65-74.
150. Thompson JR, Anderson MD, Johnson KN. Ecosystem management across ownerships: the potential for collision with antitrust laws. Conserv Biol. 2004;18:1475-81.

151. Meadows J, Herbohn J, Emtage N. Supporting cooperative forest management among small-acreage lifestyle landowners in southeast Queensland, Australia. Soc Nat Resour. 2013;26:745-61.

152. •Fischer AP, Klooster A, Cirhigiri L. Cross-boundary cooperation for landscape management: collective action and social exchange among individual private forest landowners. Landsc Urban Plan. 2019;188:151-62 This careful study from the American Pacific Northwest and Upper Midwest characterizes and explains the ways in which eight sets of private landowners cooperatively manage forest landscapes.

153 Kremen C, Merenlender AM. Landscapes that work for biodiversity and people. Science. 2018;362:eaau6020.

154. Ryan MF, Spencer RD, Keenan RJ. Private native forests in Australia: what did we learn from the Regional Forest Agreement Program. Austral For. 2002;65:141-52.

155. Tucker CM. Private versus common property forests: forest conditions and tenure in a Honduran community. Hum Ecol. 1999;27:201-30.

156. Ellsworth L. A place in the world: tenure security and community livelihoods, a literature review. Washington, D.C.: Forest Trends; 2002.

157. -Loeb CD, D'Amato AW. Large landscape conservation in a mixed ownership region: opportunities and barriers for putting the pieces together. Biol Conserv. 2020;243:108462 This case study from Vermont (U.S.) discusses strategies to fulfill large landscape conservation initiatives in places where mixed private and public land ownership is the norm.

158. Augustynczik ALD, Gutsch M, Basile M, Suckow F, Lasch P, Yousefpour R, et al. Socially optimal forest management and biodiversity conservation in temperate forests under climate change. Ecol Econ. 2020;169:106504.

159. $\bullet$ Adams VM, Mills M, Weeks R, Segan DB, Pressey RL, Gurney GG, et al. Implementation strategies for systematic conservation planning. Ambio. 2019;48:139-52 This very clear paper reviews implementation inputs, processes, and context of systematic conservation planning and identifies key barriers that can hinder attempts to bridge the assessmentimplementation gap.

160. Spies TA, McComb BC, Kennedy RSH, McGrath MT, Olsen K, Pabst RJ. Potential effects of forest policies on terrestrial biodiversity in a multi-ownership province. Ecol Appl. 2007;17:48-65.

161. De Pellegrin LI, Hoganson HM, Carson MT, Windmuller-Campione M. Recognizing spatial considerations in forest management planning. Curr For Rep. 2017;3:308-16.

162. Fitzsimons JA, Wescott G. History and attributes of selected Australian multi-tenure reserve networks. Austral Geogr. 2005;36:75-93.

163. Ghimire R, Green GT, Poudyal NC, Cordell HK. Who recreates where: implications from a National Recreation Household Survey. J For. 2016;114:458-65.

164. Best C, Wayburn LA. America's private forests: status and stewardship. Washington, D.C.: Island Press; 2013.

165. Rissman AR, Owley J, L'Roe AW, Morris AW, Wardropper CB. Public access to spatial data on private-land conservation. Ecol Soc. 2017;22:24.

166 Mason F, Zapponi L. The forest biodiversity artery: towards forest management for saproxylic conservation. iForest. 2015;9:205-16.

167. Tiebel M, Mölder A, Plieninger T. Conservation perspectives of small-scale private forest owners in Europe: a systematic review. Ambio. 2021; https://doi.org/10.1007/s13280-021-01615-w 
168. Pröbstl-Haider U, Mostegl NM, Jandl R, Formayer H, Haider W, Pukall K, et al. Bereitschaft zur Klimawandelanpassung durch Kleinwaldbesitzer in Österreich [Willingness to adapt to climate change by small forest owners in Austria]. Allg Forst- Jagdztg. 2017;188:113-26.

169. Hashida Y, Withey J, Lewis DJ, Newman T, Kline JD. Anticipating changes in wildlife habitat induced by private forest owners' adaptation to climate change and carbon policy. PLoS One. 2020;15:e0230525.

170. Best C. America's private forests: challenges for conservation. J For. 2002;100:14-7.

171. Atuo FA, Roberts K, Whitmore S, Dotters BP, Raphael MG, Sawyer SC, et al. Resource selection by GPS-tagged California spotted owls in mixed-ownership forests. For Ecol Manage. 2019;433:295-304.

172. Demant L, Bergmeier E, Walentowski H, Meyer P. Suitability of contract-based nature conservation in privately-owned forests in Germany. Nat Conserv. 2020;42:89-112.

173. Tyrväinen L, Mäntymaa E, Juutinen A, Kurttila M, Ovaskainen V. Private landowners' preferences for trading forest landscape and recreational values: a choice experiment application in Kuusamo, Finland. Land Use Pol. 2021;107:104478.
174. Charnley S, Fischer AP, Jones ET. Integrating traditional and local ecological knowledge into forest biodiversity conservation in the Pacific Northwest. For Ecol Manage. 2007;246:14-28.

175. Hatcher W, Rondeau S, Johnson DL, Johnson KN, Franklin JF. Klamath Tribes: managing their homeland forests in partnership with the USDA Forest Service. J For. 2017;115:447-55.

176. Lucero SA, Tamez S. Working together to implement the Tribal Forest Protection Act of 2004: partnerships for today and tomorrow. J For. 2017;115:468-72.

177. Van Cuong C, Dart P, Hockings M. Biosphere reserves: attributes for success. J Environ Manage. 2017;188:9-17.

178. Starrs CF, Butsic V, Stephens C, Stewart W. The impact of land ownership, firefighting, and reserve status on fire probability in California. Environ Res Lett. 2018;13:034025.

179. McComb B, Spies T, Olsen K. Sustaining biodiversity in the Oregon Coast Range: potential effects of forest policies in a multi-ownership province. Ecol Soc. 2007;12:29.

Publisher's Note Springer Nature remains neutral with regard to jurisdictional claims in published maps and institutional affiliations. 